\title{
Author Correction: Light-powered Escherichia coli cell division for chemical production
}

\author{
Qiang Ding, Danlei Ma, Gao-Qiang Liu (D, Yang Li, Liang Guo, Cong Gao, Guipeng Hu, Chao Ye, Jia Liu, Liming Liu \\ \& Xiulai Chen (1)
}

Correction to: Nature Communications https://doi.org/10.1038/s41467-020-16154-3, published online 8 May 2020.

The original version of this Article omitted a reference to previous work in reference 38, Jayaraman et al. Blue light-mediated transcriptional activation and repression of gene expression in bacteria. Nucleic Acids Res. 44, 6994-7005 (2016), when describing construction of the blue-light activation tool (BLAT). The sentence "The construction of BLAT and BLRT follows a previously

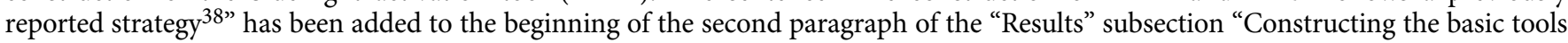
for powering cell division". Reference 38 has also been added to the sentence following: "To construct a BLAT, two units were designed and assembled (Fig. 4a): a blue optogenetics unit (BOU) to express light-sensitive protein EL222, and an activation reporter unit to replace the LuxR-binding region with an EL222-binding region by overlapping the -35 region (E. coli consensus - 35 and - 10 regions) of the LuxI promoter ${ }^{38}$."

Furthermore, Fig. 4, panels a and b, are adapted from reference 38 Figure 1, panels a and c, and this was not clear in the figure legend.

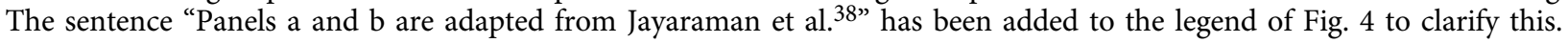

These have been corrected in both the PDF and HTML versions of the Article.

Published online: 04 November 2020 \footnotetext{
reproduction in any medium or format, as long as you give appropriate credit to the original author(s) and the source, provide a link to the Creative Commons license, and indicate if changes were made. The images or other third party material in this article are included in the article's Creative Commons license, unless indicated otherwise in a credit line to the material. If material is not included in the article's Creative Commons license and your intended use is not permitted by statutory regulation or exceeds the permitted use, you will need to obtain permission directly from the copyright holder. To view a copy of this license, visit http://creativecommons.org/licenses/by/4.0/.
}

(c) (i) Open Access This article is licensed under a Creative Commons Attribution 4.0 International License, which permits use, sharing, adaptation, distribution and

(C) The Author(s) 2020 